\section{European Community actions}

$\mathrm{S}_{\mathrm{IR}}$ - In his article "Turmoil in European Biology" (Nature 351, 91; 1991), Lennart Philipson presents his views on how to strengthen basic biology in Europe, and I should like to add my comments.

- The research and development activities of the European Communities (EC) are based on the Treaty (article 130f) which states that: "The Community's aim shall be to strengthen the scientific and technological basis of European industry and to encourage it to become more competitive at international level". This is the legal basis for all our programmes, including those containing elements of basic biology. Moreover, the EC must respect the 'subsidiary' principle, meaning that it acts only where it can add value to national or other actions.

The other organizations listed by Philipson are all perfectly respectable, and have their own aims and terms of reference, which differ from those of the EC. Others can be listed, such as the European Federation of Biotechnology, European Federation of Immunological Societies, and the European Union of Societies for Experimental Biology, which the EC helped create.

The EC mandate does not of course prevent us from developing both official and working relations with other organizations to our mutual benefit, or strengthening particular areas of research, such as plant molecular biology, which we considered insufficiently developed, even at the European Molecular Biology Laboratory.

- There have been problems in the payment of grants, not only under the SCIENCE programme. They were the consequence of changes in budgetary procedure and have now been resolved. But to write that they were "precipitated by a commissioner who failed to receive support" is untrue. These problems had nothing to do with the Commission's proposal on "Human Capital and Mobility" and the SCIENCE programme will run for its appointed duration.

- As regards genome projects, I think that EC actions on, for example, yeast, $A r a b i-$ dopsis or the human genome are seen as useful and well-managed by informed researchers and decision-makers, although the resources we devote to them are limited.

- Our review process is certainly not perfect and, like any system, can be improved. Everybody knows, and surveys show, that peer review is preferred by most good scientists. What is the basis of Philipson's allegation that the EC "has a questionable peer review process and often distributes funds on geographical rather than scientific criteria"? Is it a matter of quality? Many of those who evaluated the BRIDGE (biotechnology) proposals had been fellows of the European Molecular Biology Organization. Is it representativeness? Our experts come both from academic institutions and industry. Is it confidentiality or anonymity? We go to extremes to ensure both of these.

The EC does not use geographical rather than scientific criteria. There are first-class scientists in all member states, but our basic criterion of selection is scientific quality. Only then does the EC promote collaborations between countries and regions, between industry and agriculture, between industry and academic institutions, between users and producers, and so on.

- Philipson seems to imply that the EC's usual mechanism is the "limited call for proposals". Our normal procedure is the "open call for proposals". Limited calls are exceptions, used only when we are certain that only one or very few laboratories are performing a precisely defined task.

- As for the proposed remedy, it seems to me more grandiose than realistic. What should be frightening to Philipson is that it could be examined by science administrators who have "either failed in research or have been trained in law or economics", and that the "unqualified administrators" or the EC could still play a role in this process.

F. VAN HOECK

Commission of European

Director of Biology,

Communities,

Rue de la Loi 200,

B-1049 Bruxelles, Belgium

SIR - Lennart Philipson, in characteristic fashion, pulls no punches when he boldly identifies a problem in most science administrators who influence decision-making that they "either have failed in research or have been trained in law or economics, their loyalties resting entirely with the organizations or the ministry for which they work".

This is because biologists who fail to achieve tenure have no attractive option and administration is an alternative career. The problem could be reduced, however, if more doctoral students were recruited from the professional branches of biology medicine, dentistry and veterinary sciencewhich already have natural career paths in a return to clinical practice. The talented ones would stay in basic research.

The high earning power in law and accountancy would suggest that anyone from those fields seeking a career in administration is unsuitable by definition. Furthermore, the UK Charity Commission is unhappy if administrative and fund-raising costs exceed 5 per cent and this is a yardstick with which to cull the European science mandarins. Charles Dickens allowed $\mathrm{Mr}$ Micawber to outline to David Copperfield the principle of good financial management. LARS H. BREIMER

Department of Chemical Pathology and Human Metabolism.

Royal Free Hospital School of Medicine,

London NW3 2PF, UK

\section{Advance from Australia?}

$\mathrm{S}_{\mathrm{IR}}$ - As an expatriate Australian researcher, hoping for a future in my homeland, it is with great dismay that I see the Australian university system once again a subject of international concern (Nature 350, 447 \& $452 ; 1991)$. It would appear that the Australian government sees fit to dismantle the Australian National University in the name of economic efficiency and a perceived political need to direct its research effort.

Unfortunately, Australia seems either economically unable or politically unwilling to allow the development of truly outstanding research-driven universities. It is true that there is a lack of academic tradition in the country, but with most universities in existence for less than a century, one cannot be surprised by this.

The Australian government's need to control and direct university research may stem from its inexperience. After all, were the structure of DNA, restriction-modification or DNA sequencing, the cornerstones of modern biology and medical research, discovered because of a government-imposed directive or decree? Independent enquiry, not strategic planning and bureaucratic intervention, underlies scientific discovery.

But in spite of the problems, university education in Australia has not been all bad. The number of Australian-educated scientists doing outstanding research in both the United States and Europe attests to this fact. Expatriate Australian scientists head departments in some of the world's best research institutes, universities and hospitals and are found on the editorial boards of leading international journals.

The problem with Australia seems to be not with the quality of education but the quality of its academic environment and quantity of academic opportunity. Many of the best leave the country after training because of the shortage of suitable employment or lack of tolerance and respect for academic achievement by the Australian population. Many who return after an extended stay in the United States or Europe find they are locked out of the system and, after pursuing successful careers overseas, cannot understand why Australians do not support academic excellence.

Academic research is part of the spectrum of human endeavour. If tolerated and given the opportunity, these endeavours can, and do, make important contributions to a country's economic, social and cultural wellbeing. Europeans and North Americans have learned this. Unfortunately, Australians have not.

Jan Rohozinski

Department of Virology and Molecular Biology,

St Jude Children's Research Hospital, 332 North Lauderdale, PO Box 318 , Memphis, Tennessee 38101, USA 